\title{
Jurnal Pendidikan Matematika
}

\section{Analisis Kemampuan Pemecahan Masalah Matematika Siswa Sekolah Menengah Pertama Berdasarkan Gaya Kognitif}

\author{
Lihar Raudina Izzati ${ }^{1}$, Erlinda Rahma Dewi ${ }^{2}$, Andika Wisnu ${ }^{3}$ \\ ${ }^{1,2}$ Fakultas Ilmu Tarbiyah Institut Agama Islam Negeri Surakarta \\ ${ }^{3}$ SDN Wonotingal Kota Semarang \\ 1Email: lihar.izzati@iain-surakarta.ac.id
}

Published: 7 July, 2021.

\begin{abstract}
Problem-solving ability is a characteristic of mathematical activities and a major ability in developing mathematical understanding. Mathematical problem-solving ability can be seen from several dimensions, one of which is cognitive style. Cognitive style is a unique way for each individual to acquire, process, store, use the information to respond to tasks or situations, and build knowledge. FD and FI cognitive styles are one type of cognitive style that are categorized by general ways of thinking, solving problems, learning, and dealing with other people so that they have a relationship with problem-solving abilities. The subjects in this study involved 72 students (around the age of 13-14 years), namely 33 students with FD cognitive style and 39 students with FI cognitive style. The problemsolving ability test instrument in this study was a mathematical problem-solving ability test that had been validated by experts and tested for reliability. The cognitive style test instrument is the Group Embedded Figure Test (GEFT) item developed by Witkin. The problem-solving ability of junior high school students with FI cognitive style is better than FD students even though the difference is not much different.
\end{abstract}

Keywords: cognitive style; mathematics; problem solving skill

\begin{abstract}
Abstrak
Kemampuan pemecahan masalah merupakan karakteristik aktivitas matematika dan kemampuan utama dalam mengembangkan pemahaman matematika. Kemampuan pemecahan masalah matematika dapat dilihat dari beberapa dimensi, salah satunya adalah gaya kognitif. Gaya kognitif adalah cara unik setiap individu untuk memperoleh, memproses, menyimpan, menggunakan informasi untuk merespon tugas atau situasi dan membangun pengetahuannya. Gaya kognitif FD dan FI merupakan salah satu tipe gaya kognitif yang dikategorisasikan dengan cara umum berpikir, memecahkan masalah, belajar dan berurusan dengan orang lain sehingga mempunyai relasi dengan kemampuan pemecahan masalah. Subjek dalam penelitian ini melibatkan 72 siswa (sekitar usia 13-14 tahun) yaitu 33 siswa dengan gaya kognitif FD dan 39 siswa dengan gaya kognitif FI. Instrumen tes kemampuan pemecahan masalah dalam penelitian ini adalah soal kemampuan pemecahan masalah matematika yang divalidasi oleh para ahli dan diuji reliabilitasnya. Instrumen tes gaya kognitif adalah soal Group Embedded Figure Test (GEFT) yang dikembangkan oleh Witkin. Kemampuan pemecahan masalah siswa sekolah menengah pertama dengan gaya kognitif FI lebih baik daripada siswa FD walaupun perbedaannya tidak jauh berbeda.
\end{abstract}

Kata kunci: gaya kognitif; kemampuan pemecahan masalah; matematika 


\section{PENDAHULUAN}

Kemampuan siswa untuk memahami konsep merupakan salah satu fokus perbaikan bagi pendidikan dan kunci dari pendidikan di abad 21 yang dapat digunakan sebagai basis untuk menentukan kemampuan pemecahan masalah (Geller, Son dan Stigler, 2017; Wismath et al, 2015). Kemampuan pemecahan masalah menjadi salah satu kemampuan penting di abad 21 yang harus siswa punyai karena siswa yang mempunyai kemampuan pemecahan yang baik akan mampu menikmati kehidupan sehari-hari dan di tempat kerjanya (Khalid, et al, 2020). Kemampuan pemecahan masalah juga merupakan karakteristik aktivitas matematika dan kemampuan utama dalam mengembangkan pemahaman matematika (NCTM, 2000). Kemampuan pemecahan masalah merupakan keahlian atau potensi yang harus dimiliki siswa untuk menyelesaikan masalah dan dapat digunakan dalam kehidupan sehari-hari (Gunantara, Suarjana, dan Riastini, 2014: 5).

Kemampuan pemecahan masalah adalah kemampuan untuk memecahkan masalah, terutama dalam masalah yang abstrak atau non rutin (Zamakhsyari dan Rahayu, 2020). Kemampuan ini mendeskripsikan bagaimana seseorang memahami masalah, mencari solusi alternatif, merencanakan solusi, menyelesaikan masalah dan memeriksa solusi yang digunakan (Sin, Sihes dan Hamidon, 2020). Kemampuan pemecahan masalah juga dapat digunakan untuk memprediksi hasil belajar siswa (Rahmawati, Sulisworo, dan Prasetyo, 2020).

Siswa dapat belajar untuk menggunakan kemampuan matematika mereka dengan cara baru, mengembangkan pemahaman yang lebih dalam tentang ide matematika dan merasakan pengalaman menjadi ahli matematika dengan cara memecahkan masalah (Badger et al, 2012). Kemampuan pemecahan masalah siswa dapat dilatih dengan cara menambah aktivitas pemecahan masalah sehari-hari dalam aktivitas pembelajaran matematika (Chabibah, Siswanah dan Tsani, 2019; Suryaningtyas, 2017). Kemampuan pemecahan masalah membutuhkan implementasi strategi yang pasti yang dapat membuat siswa mengembangkan banyak ide dengan cara mengembangkan dan menguji hipotesis (Son, Darhim dan Fatimah, 2020). Siswa yang kemampuan pemecahan masalah matematikanya sudah berada pada kategori tinggi dan sangat tinggi seharusnya sudah mampu melakukan semua indikator kemampuan pemecahan masalah matematika dengan skor maksimal. Oleh karena itu, dalam penelitian ini akan dianalisis kemampuan pemecahan masalah matematika siswa yang ada pada kategori tinggi dan sangat tinggi yaitu siswa yang mendapatkan nilai skor tes kemampuan pemecahan masalah lebih dari 58,33 .

Kemampuan pemecahan masalah matematika siswa dapat dilihat dari beberapa dimensi, salah satunya adalah gaya kognitif. Gaya kognitif merupakan salah satu variabel penting yang dapat mempengaruhi kemampuan pemecahan masalah siswa (Mefoh, et al, 
2017). Gaya kognitif memegang peran penting dalam pemecahan masalah (Vendiagrys, Junaedi dan Masrukan, 2015). Hasil penelitian menunjukkan bahwa ada pengaruh yang signifikan dan korelasi yang positif antara gaya kognitif dan kemampuan pemecahan masalah, yaitu sebesar 61\% (Jena, 2014; Ulya, 2015).

Gaya kognitif adalah perbedaan sudut pandang seseorang dalam melihat, mengetahui dan mengatur informasi (Pramusinta, et al, 2019). Gaya kognitif adalah bentuk konsistensi sikap yang menunjukkan bagaimana setiap individu memperoleh dan memproses informasi (Hsieh, et al, 2020; Sellah, Jacinta, dan Helen, 2017). Dengan kata lain, gaya kognitif adalah cara unik setiap individu untuk memperoleh, memproses, menyimpan, menggunakan informasi untuk merespon tugas atau situasi dan membangun pengetahuannya (Sellah, Jacinta dan Helen, 2017; Margunayasa, et al, 2019).

Gaya kognitif dibagi menjadi beberapa tipe, yaitu field-dependent dan fieldindependent, impulsif dan reflektif, perseptif dan reseptif, intuitif dan sistematis (Volkova dan Rusalov, 2016). Field-dependent (FD) dan Field-Independent (FI) adalah gaya kognitif yang paling populer (Mefoh, et al, 2017). Gaya kognitif FD dan FI adalah gaya kognitif yang dikategorisasikan dengan cara umum berpikir, memecahkan masalah, belajar dan berurusan dengan orang lain (Abrams dan Belgrave, 2013). Definisi ini secara eksplisit mengilustrasikan bahwa gaya kognitif FD dan FI mempunyai relasi dengan kemampuan pemecahan masalah.

Gaya kognitif FD cenderung melihat masalah secara global, mendeskripsikan orientasi siswa ke dunia luar ketika menyelesaikan masalah, sedangkan gaya kognitif FI cenderung melihat masalah sampai pada komponen pembentuk, mencerminkan kemampuan siswa untuk mengandalkan pengetahuan dan pengalaman mereka ketika memecahkan masalah (Onyekuru, 2015; Volkova dan Rusalov, 2016). Katakteristik gaya kognitif FD yaitu mempunyai ketertarikan terhadap orang lain, ramah dengan orang lain, mempunyai rasa sosial yang tinggi, pasif dan bergantung pada orang lain, tidak dapat menangani objek yang dianggap terpisah dari elemen sekitarnya, sedangkan gaya kognitif FI tidak terlalu tertarik terhadap orang lain, menjaga jarak dengan orang lain, lebih memilih berada pada situasi non sosial, aktif dan tidak bergantung pada orang lain, dapat menangani objek yang dianggap terpisah dari elemen sekitarnya (Al-Salameh, 2011; Karamaerouz, Abdi dan Laei, 2013; Safaruddin et al, 2020). Terdapat perbedaan antara siswa dengan gaya kognitif FD dan FI dalam memecahkan masalah, dimana gaya kognitif FD cenderung mengandalkan pengaruh dari luar, sedangan gaya kognitif FI cenderung lebih mandiri dan percaya diri.

Berdasarkan penjelasan di atas, maka tujuan penulisan ini adalah untuk menganalisis bagaimana kemampuan pemecahan masalah matematika siswa SMP yang ada di kategori tinggi dan sangat tinggi ditinjau dari gaya kognitif FD dan FI. Kemampuan 
pemecahan masalah dalam penelitian ini meliputi pemahaman masalah, perencanaan penyelesaian masalah, pelaksanaan rencana penyelesaian, menginterpretasikan hasil yang diperoleh.

\section{METODE}

Penelitian ini merupakan penelitian deskriptif kualitatif. Penelitian ini dilakukan di sekolah menengah pertama di Ungaran, Indonesia. Subjek dalam penelitian ini melibatkan 72 siswa (sekitar usia 13-14 tahun) yaitu 33 siswa pada kategori tinggi dan sangat tinggi dengan gaya kognitif FD dan 39 siswa kategori tinggi dan sangat tinggi dengan gaya kognitif FI.

Instrumen tes kemampuan pemecahan masalah dalam penelitian ini adalah soal kemampuan pemecahan masalah matematika. Soal ini terdiri dari 5 soal dalam bentuk uraian. Indikator aspek kemapuan pemecahan masalah yang digunakan mengacu pada pendapat Polya (2004: 5-6) yaitu: 1) memahami masalah, 2) merancang rencana untuk memperoleh penyelesaian, 3) melaksanakan rencana dan mengkonfirmasikan kebenaran langkah-langkah pelaksanaannya, 4) melihat kembali hasil penyelesaian dan mendiskusikannya. Namun, pada tahap melihat kembali hasil penyelesaian dan mendiskusikannya, siswa dibiasakan untuk mengecek hasil pekerjaannya dengan hasil pada pembahasan dan menginterpretasikan hasil yang diperoleh. Oleh karena itu, penilaian pada tahap melihat kembali hasil penyelesaian dan mendiskusikannya diganti dengan menginterpretasikan hasil yang diperoleh.

Validitas yang digunakan untuk instrumen tes kemampuan pemecahan masalah adalah validitas isi. Validitas isi tes dapat diketahui dari kesesuaian tes dengan kisi-kisi, SK dan KD. Pengujian validitas isi tes pada penelitian ini diuji dengan cara telaah ahli (judgment expert). Dalam penelitian ini ada tiga orang ahli yang memvalidasi instrumen. Uji reliabilitas tes kemampuan pemecahan masalah menggunakan rumus Alpha dari Cronbanch dan diperoleh nilai 0,821 yang berarti soal tes kemampuan pemecahan masalah reliabel. Rubrik penilaian kemampuan pemecahan masalah ada pada Tabel 1 .

Tabel 1. Pedoman Penskoran Tes Kemampuan Pemecahan Masalah

\begin{tabular}{|c|c|c|}
\hline Indikator & Skor & Keterangan \\
\hline \multirow{3}{*}{ Pemahaman masalah } & 0 & $\begin{array}{l}\text { Salah menginterpretasikan soal/tidak ada jawaban sama } \\
\text { sekali. }\end{array}$ \\
\hline & 1 & Salah menginterpretasikan sebagian soal. \\
\hline & 2 & Memahami masalah secara keseluruhan. \\
\hline \multirow{3}{*}{$\begin{array}{l}\text { Perencanaan } \\
\text { penyelesaian masalah }\end{array}$} & 0 & Tidak menggunakan strategi sama sekali. \\
\hline & 1 & $\begin{array}{lllll}\begin{array}{l}\text { Menggunakan strategi yang tidak tepat untuk } \\
\text { menyelesaikan masalah. }\end{array} & & & & \\
\end{array}$ \\
\hline & 2 & $\begin{array}{l}\text { Menggunakan strategi yang relevan, mengarah pada } \\
\text { jawaban yang benar tetapi belum lengkap untuk } \\
\text { menyelesaikan masalah. }\end{array}$ \\
\hline
\end{tabular}




\begin{tabular}{ccl}
\hline Indikator & Skor & \multicolumn{3}{c}{ Keterangan } \\
\hline & 3 & $\begin{array}{l}\text { Menggunakan strategi yang relevan, mengarah pada } \\
\text { jawaban yang benar, dan lengkap. }\end{array}$ \\
\hline & 0 & Tidak ada pelaksanaan strategi sama sekali. \\
\cline { 2 - 4 } $\begin{array}{c}\text { Pelaksanaan rencana } \\
\text { penyelesaian }\end{array}$ & 2 & $\begin{array}{l}\text { Salah dalam melaksanakan strategi. } \\
\text { dalaksanakan strategi yang direncanakan tetapi salah }\end{array}$ \\
\cline { 2 - 4 } $\begin{array}{c}\text { Menginterpretasikan } \\
\text { hasil yang diperoleh }\end{array}$ & 1 & $\begin{array}{l}\text { Melaksanakan strategi yang telah direncanakan dan } \\
\text { perhitungan secara tepat. }\end{array}$ \\
\cline { 2 - 4 } & 0 & $\begin{array}{l}\text { Tidak menginterpretasikan hasil yang diperoleh. } \\
\text { kurang tepat. }\end{array}$ \\
\hline
\end{tabular}

Sedangkan, instrumen tes gaya kognitif adalah soal Group Embedded Figure Test (GEFT) yang dikembangkan oleh Witkin. Tes tersebut berguna untuk mengelompokkan siswa berdasarkan gaya kognitifnya. Sebelumnya siswa terlebih dahulu diberi soal Group Embedded Figure Test (GEFT) yang terdiri dari tiga tahapan dengan total waktu pengerjaan selama 25 menit, yaitu: a) tahap pertama terdiri dari 7 butir soal dengan waktu pengerjaan maksimal 5 menit, dimaksudkan sebagai latihan bagi siswa, b) tahap kedua terdiri dari 9 butir soal dengan waktu pengerjaan maksimal 10 menit, dimaksudkan sebagai penilaian bagi siswa, c) tahap ketiga sama halnya dengan tahap kedua yaitu 9 butir soal dengan waktu 10 menit, dimaksudkan sebagai penilaian bagi siswa. Ketentuan penilaian GEFT memberikan skor 1 untuk butir soal yang dijawab benar, memberi skor 0 jika salah. Siswa yang memperoleh skor 0-9 digolongkan sebagai siswa bergaya kognitif Field Dependent, skor antara 10-18 digolongkan sebagai siswa dengan gaya kognitif Field Independent.

Data dalam penelitian ini adalah hasil dari tes kemampuan pemecahan masalah dan hasil Group Embedded Figure Test (GEFT) yang dikembangkan oleh Witkin. Hasil tes kemampuan pemecahan masalah dianalisis untuk mengetahui karakteristik kemampuan pemecahan masalah siswa berdasarkan gaya kognitif.

\section{HASIL DAN PEMBAHASAN}

Pemecahan masalah dalam konteks matematika sekolah mengacu pada situasi dimana siswa terlibat dalam tugas pemecahan masalah sebagai bagian dari urutan instruksional dan sebagai aplikasi terhadap konsep, prinsip, dan algoritma matematika yang diajarkan (Jurdak, 2016: 55). Pemecahan masalah bukanlah suatu proses sederhana yang selesai ketika jawaban ditemukan, namun suatu proses saintifik yang memungkinkan adanya peningkatan dari memahami suatu masalah menjadi mengevaluasi suatu solusi permasalahan (Ozturk dan Guven, 2016: 411). 
Berikut persentase rata-rata siswa FD pada kategori tinggi dan sangat tinggi pada skor tes kemampuan pemecahan masalah matematika dari masing-masing indikator yang terlihat pada Tabel 2.

Tabel 2. Persentase Rata-Rata Siswa FD pada Kategori Tinggi dan Sangat Tinggi Berdasarkan Indikator

\begin{tabular}{|c|c|c|}
\hline Indikator & Skor & $\begin{array}{c}\text { Persentase } \\
\text { Siswa FD }\end{array}$ \\
\hline \multirow{3}{*}{ Pemahaman masalah } & 0 & $0,00 \%$ \\
\hline & 1 & $0,61 \%$ \\
\hline & 2 & $99,39 \%$ \\
\hline \multirow{4}{*}{ Perencanaan penyelesaian masalah } & 0 & $0,00 \%$ \\
\hline & 1 & $9,09 \%$ \\
\hline & 2 & $29,09 \%$ \\
\hline & 3 & $61,82 \%$ \\
\hline \multirow{4}{*}{$\begin{array}{l}\text { Pelaksanaan rencana } \\
\text { penyelesaian }\end{array}$} & 0 & $0,00 \%$ \\
\hline & 1 & $29,70 \%$ \\
\hline & 2 & $46,06 \%$ \\
\hline & 3 & $24,24 \%$ \\
\hline \multirow{3}{*}{$\begin{array}{c}\text { Menginterpretasikan hasil yang } \\
\text { diperoleh }\end{array}$} & 0 & $0,00 \%$ \\
\hline & 1 & $76,97 \%$ \\
\hline & 2 & $23,03 \%$ \\
\hline
\end{tabular}

Tabel 2 menunjukkan bahwa rata-rata siswa FD pada kategori tinggi dan sangat tinggi sudah mampu memahami masalah, menggunakan strategi yang relevan, mengarah pada jawaban yang benar, dan lengkap, melaksanakan strategi yang direncanakan tetapi salah dalam melakukan perhitungan dan menginterpretasikan hasil yang diperoleh tetapi masih kurang tepat. Hal ini dikarenakan siswa FD cenderung melihat masalah secara global, mendeskripsikan orientasi siswa ke dunia luar ketika menyelesaikan masalah, pasif dan bergantung pada orang lain, tidak dapat menangani objek yang dianggap terpisah dari elemen sekitarnya, cenderung mengandalkan pengaruh dari luar, sulit untuk memproses informasi, mengubah persepsi dengan mudah ketika informasi dimanipulasi dalam konteks, cenderung menerima struktur yang sudah ada karena kurangnya restrukturisasi (Al-Salameh, 2011; Karamaerouz, Abdi, dan Laei, 2013; Onwumere dan Reid, 2014; Onyekuru, 2015; Volkova dan Rusalov, 2016; Safaruddin, et al, 2020).

Berikut persentase rata-rata siswa FI pada kategori tinggi dan sangat tinggi pada skor tes kemampuan pemecahan masalah matematika dari masing-masing indikator yang terlihat pada Tabel 3 . 
Tabel 3. Persentase Rata-Rata Siswa FI pada Kategori Tinggi dan Sangat Tinggi Berdasarkan Indikator

\begin{tabular}{|c|c|c|}
\hline Indikator & Skor & $\begin{array}{l}\text { Persentase } \\
\text { Siswa FI }\end{array}$ \\
\hline \multirow{3}{*}{ Pemahaman masalah } & 0 & $0,00 \%$ \\
\hline & 1 & $0,00 \%$ \\
\hline & 2 & $100,00 \%$ \\
\hline \multirow{4}{*}{ Perencanaan penyelesaian masalah } & 0 & $0,00 \%$ \\
\hline & 1 & $5,64 \%$ \\
\hline & 2 & $23,08 \%$ \\
\hline & 3 & $71,28 \%$ \\
\hline \multirow{4}{*}{$\begin{array}{l}\text { Pelaksanaan rencana } \\
\text { penyelesaian }\end{array}$} & 0 & $0,00 \%$ \\
\hline & 1 & $23,59 \%$ \\
\hline & 2 & $37,95 \%$ \\
\hline & 3 & $38,46 \%$ \\
\hline \multirow{3}{*}{$\begin{array}{l}\text { Menginterpretasikan hasil yang } \\
\text { diperoleh }\end{array}$} & 0 & $0,00 \%$ \\
\hline & 1 & $62,05 \%$ \\
\hline & 2 & $37,95 \%$ \\
\hline
\end{tabular}

Tabel 3 menunjukkan bahwa rata-rata siswa FI pada kategori tinggi dan sangat tinggi sudah mampu memahami masalah, menggunakan strategi yang relevan, mengarah pada jawaban yang benar, dan lengkap, melaksanakan strategi yang telah direncanakan dan perhitungan secara tepat dan menginterpretasikan hasil yang diperoleh tetapi masih kurang tepat. Hal ini dikarenakan siswa FI cenderung melihat masalah sampai pada komponen pembentuk, mencerminkan kemampuan siswa untuk mengandalkan pengetahuan dan pengalaman mereka ketika memecahkan masalah, aktif dan tidak bergantung pada orang lain, dapat menangani objek yang dianggap terpisah dari elemen sekitarnya, umumnya mandiri, kompetitif dan percaya diri (Al-Salameh, 2011; Karamaerouz, Abdi dan Laei, 2013; Onwumere dan Reid, 2014; Onyekuru, 2015; Volkova dan Rusalov, 2016; Safaruddin, et al, 2020).

Dilihat dari Tabel 2 dan 3, rata-rata siswa FD dan FI pada kategori tinggi dan sangat tinggi sudah mampu memahami masalah, menggunakan strategi yang relevan, mengarah pada jawaban yang benar, dan lengkap, menginterpretasikan hasil yang diperoleh, tetapi terdapat perbedaan dalam pelaksanaan penyelesaian masalah, dimana siswa FD pada kategori tinggi dan sangat tinggi masih salah dalam melakukan perhitungan, sedangkan siswa FI pada kategori tinggi dan sangat tinggi sudah mampu melakukan perhitungan secara tepat. Selain itu, baik siswa FD dan FI juga belum tepat dalam menginterpretasikan hasil yang diperoleh.

\section{SIMPULAN}

Kemampuan pemecahan masalah siswa pada kategori tinggi dan sangat tinggi sekolah menengah pertama dengan gaya kognitif FD sudah mampu memahami masalah, 
menggunakan strategi yang relevan, mengarah pada jawaban yang benar, dan lengkap, melaksanakan strategi yang direncanakan tetapi salah dalam melakukan perhitungan dan menginterpretasikan hasil yang diperoleh tetapi masih kurang tepat. Sedangkan, kemampuan pemecahan masalah siswa pada kategori tinggi dan sangat tinggi sekolah menengah pertama dengan gaya kognitif FI sudah mampu memahami masalah, menggunakan strategi yang relevan, mengarah pada jawaban yang benar, dan lengkap, melaksanakan strategi yang telah direncanakan dan perhitungan secara tepat dan menginterpretasikan hasil yang diperoleh tetapi masih kurang tepat. Walaupun kemampuan pemecahan masalah siswa FD dan FI berada pada kategori tinggi dan sangat tinggi, siswa belum melakukan semua indikator kemampuan pemecahan masalah dengan skor maksimal. Oleh karena itu, pendidik yang ada di sekolah menengah pertama harus dapat menentukan model dan metode pembelajaran yang tepat agar dapat meningkatkan kemampuan pemecahan masalah siswa FD dan FI pada kategori tinggi dan sangat tinggi khususnya indikator pelaksanaan rencana penyelesian dan menginterpretasikan hasil yang diperoleh karena persentase siswa yang mendapatkan skor maksimum pada masingmasing indikator masih kurang dari $60 \%$ siswa.

\section{REFERENSI}

Abrams, J., \& Belgrave, F. Z. (2013). Field Dependence. The Encyclopedia of CrossCultural Psychology, II(1): 1-3. https://doi.org/10.1002/978-3-030-20223-1

Al-Salameh, E. M. (2011). A Study of Al-Balqa' Applied University Students Cognitive Style. International Education Studies, 4(3): 189-193. https://doi.org/10.5539/ies.v4n3p189

Badger, M. S., et al. (2012). Teaching Problem-Solving in Undergraduate Mathematics. UK: Conventry University.

Chabibah, L. N., Siswanah, E., \& Tsani, D. F. (2019). Analisis Kemampuan Pemecahan Masalah Siswa dalam Menyelesaikan Soal Cerita Barisan Ditinjau dari Adversity Quotient. Jurnal Pendidikan Universitas Garut, 13(1): 103-109. https://doi.org/10.21831/pg.v14i2.29024

Geller, E. H., Son, J. Y., \& Stigler, J. W. (2017). Conceptual Explanations and Understanding Fraction Comparisons. Learning and Instruction, 52, December 2017: 122-129. https://doi.org/10.1016/j.learninstruc.2017.05.006

Gunantara, G., Suarjana, I. M., \& Riastini, P. N. (2014). Penerapan Model Pembelajaran Problem Based Learning untuk Meningkatkan Kemampuan Pemecahan Masalah Matematika Siswa Kelas V. Jurnal Mimbar PGSD Universitas Pendidikan Ganesha, 2(1):1-10. https://doi.org/10.23887/jipgsd.v2i1.2058 
Hsieh, S., et al. (2020). ERP Correlates of a Flanker Task with Varying Levels of Analytic-Holistic Cognitive Style. Personality and Individual Differences, 153 153, 15 January 2020, 109673. https://doi.org/10.1016/j.paid.2019.109673

Jena, P. C. (2014). Cognitive Styles and Problem Solving Ability of Undergraduate Students. International Journal of Education and Psychological Research, 3(2): 71-76.

Jurdak, M. (2016). Learning and Teaching Real World Problem Solving in School Mathematics: A Multiple Perspective Framework for Crossing the Boundary. Switzerland, Swiss: Nature.

Karamaerouz, M. J., Abdi, A. A., \& Laei, S. (2013). Learning by Employing Educational Multimedia in Field-Dependent and Field-Independent Cognitive Styles. Universal Journal of Educational Research, 1(4): 298-302. https://doi.org/10.13189/ujer.2013.010404

Khalid, M., et al. (2020). Enhancing Creativity and Problem Solving Skills Through Creative Problem Solving in Teaching Mathematics. Creativity Studies, 13(2): 270-291. https://doi.org/10.3846/cs.2020.11027

Margunayasa, I. G., et al. (2019). The Effect of Guided Inquiry Learning and Cognitive Style on Science Learning Achievement. International Journal of Instruction, 12(1): 737-750. https://doi.org/10.29333/iji.2019.12147a

Mefoh, P. C., et al. (2017). Effect of Cognitive Style and Gender on Adolescents' Problem Solving Ability. Thinking Skills and Creativity, 25: 47-52. https://doi.org/10.1016/j.tsc.2017.03.002

NCTM. (2000). Principles and Standards for School Mathematics. USA: NCTM.

Onwumere, O., \& Reid, N. (2014). Field Dependency and Performance in Mathematics. European Journal of Educational Research, 3(1): 43-57. https://doi.org/10.12973/eu-jer.3.1.43

Onyekuru, B. U. (2015). Field Dependence-Field Independence Cognitive Style, Gender, Career Choice and Academic Achievement of Secondary School Students in Emohua Local Government Area of Rivers State. Journal of Education and Practice, 6(10): 76-86.

Ozturk, T. \& Guven, B. (2016). Evaluating Students; Beliefs in Problem Solving Process: A Case Study. Eurasia Journal of Mathematics, Science \& Technology Education, 12(2): 411-429. https://doi.org/10.12973/eurasia.2016.1208a

Polya, G. (2004). How to Solve It: A New Aspect of Mathematical Method. New Jersey, USA: Princeton University Press.

Pramusinta, Y., et al. (2019). Exploring Metacognitive and Critical Thinking Skills of 
Pre-Service Elementary School Teachers Through Discovery Learning Method by Integrating Various Cognitive Styles. Journal for the Education of Gifted Young Scientists, 7(4): 999-1017. https://doi.org/10.17478/jegys.614028

Rahmawati, T. D., Sulisworo, D., \& Prasetyo, E. (2020). Enhancing Students' Motivation and Problem Solving Skills in Mathematics Using Guided Discovery Learning. Universal Journal of Educational Research, 8(12), 6783-6789. https://doi.org/10.13189/ujer.2020.081244.

Safaruddin, et al. (2020). The Effect of PJBL with WBL Media and Cognitive Style on Students' Understanding and Science-Integrated Concept Application. Jurnal Pendidikan IPA Indonesia, 9(3): 384-395. https://doi.org/10.15294/jpii.v9i3.24628

Sellah, L., Jacinta, K., \& Helen, M. (2017). Analysis of Student-Teacher Cognitive Styles Interaction: An Approach to Understanding Learner Performance. Journal of Education and Practice, 8(14): 10-20.

Sin, Y. W., Sihes, A. J., \& Hamidon, M. (2020). A Review of Problem-Solving Skills in Mathematics and Cooperative Learning Among Primary School Students. International Journal of Psychosocial Rehabilitation, 24(5): 605-613. https://dx.doi.org/10.37200/IJPR/V24I5/PR201725

Son, A. L., Darhim \& Fatimah, S. (2020). Students' Mathematical Problem-Solving Ability Based on Teaching Models Intervention and Cognitive Style. Journal on Mathematics Education, 11(2): 209-222.

http://dx.doi.org/10.22342/jme.11.2.10744.209-222

Suryaningtyas, C. P. (2017). Pengembangan Perangkat Pembelajaran Matematika dengan PMRI untuk Meningkatkan Kemampuan Pemecahan Masalah dan Komunikasi Matematika. Pythagoras: Jurnal Pendidikan Matematika, 12(2): 200-209. https://doi.org/10.21831/pg.v12i2.14876

Ulya, H. (2015). Hubungan Gaya Kognitif dengan Kemampuan Pemecahan Masalah Matematika Siswa. Jurnal Konseling Gusjigang, 1(2): 1-12. https://doi.org/10.24176/jkg.v1i2.410

Vendiagrys, L., Junaedi, I., \& Masrukan. (2015). Analisis Kemampuan Pemecahan Masalah Matematika Soal Setipe TIMSS Berdasarkan Gaya Kognitif Siswa pada Pembelajaran Model Problem Based Learning. Unnes Journal of Mathematics Education Research, 4(1): 34-41. https://journal.unnes.ac.id/sju/index.php/ujmer/article/view/6905

Volkova, E. V., \& Rusalov, V. M. (2016). Cognitive Styles and Personality. Personality and Individual Differences, 99: 266-271. https://doi.org/10.1016/j.paid.2016.04.097

Wismath, S., et al. (2015). Threshold Concepts in the Development of Problem-Solving Skills. Teaching \& Learning Inquiry, 3(1): 63-73. https://doi.org/10.20343/teachlearninqu.3.1.63 
Jurnal Pendidikan Matematika Universitas Lampung, Vol. 9, No. 2, 2021

Zamakhsyari, \& Rahayu, S. (2020). Fostering Ill-Stuctured Problem-Solving Skills of Chemistry Students Using Socioscientific Issues as Learning Contexts. AIP Conference Proceedings, 2215, art. no. 020027. 